\title{
Bending Strength of Board Manufactured from Sawdust, Rice Husk and Charcoal ${ }^{1}$
}

\author{
Jung-Woo HWANG ${ }^{2} \cdot$ Seung-Won $\mathrm{OH}\left(1^{2, \dagger}\right.$
}

\begin{abstract}
Purpose of this study is reviewing the use method for the sawdust (sawmilling by-product) and rice husk (Agriculture by-product) by adding charcoal, an eco-friendly material. Mixed composite boards were manufactured with those materials with each density and mixing ratio, and bending performance was investigated. When the addition ratio of sawdust, rice husk and charcoal is 50:20:20 and the resin addition ratio is $10 \%$, as the density of the prepared mixed board ranges from $0.5 \mathrm{~g} / \mathrm{cm}^{3}$ to $0.7 \mathrm{~g} / \mathrm{cm}^{3}$, the bending strength was $0.42 \sim 3.24 \mathrm{~N} / \mathrm{mm}^{2}$, dynamic modulus of elasticity was $94.5 \sim 888.4 \mathrm{~N} / \mathrm{mm}^{2}$, and the static modulus of elasticity was in the range of $31.4 \sim 220.7 \mathrm{~N} / \mathrm{mm}^{2}$. As the density increased, the bending performance increased, indicating that the density had a significant effect on the bending performance. In a board prepared by setting the density of $0.6 \mathrm{~g} / \mathrm{cm}^{3}$, the addition ratio of sawdust to $50 \%$, and the addition ratio of rice husk and charcoal at different ratios, the bending performance showed a tendency to decrease as the addition ratio of charcoal increased. The relationship between the addition ratio of rice husk and charcoal, bending strength, resonance frequency, and dynamic and static bending modulus showed a rather low correlation with the values of the coefficient of determination $\left(R^{2}\right)$ of $0.4562,0.4310,0.4589$, and 0.5847 , respectively. Thus, we found that the effect of the addition ratio on the bending performance was small.
\end{abstract}

Keywords: rice husk, sawdust, charcoal, composite board, bending strength, dynamic modulus of elasticity

\section{INTRODUCTION}

Nowadays, most of the modern life takes place indoors and so, interest in wood and wood materials, which are eco-friendly building materials, is increasing according to problems related to the indoor environment and personal health problems. Accordingly, it is necessary to cope with the situation of increasing consumption of wood and wood materials, developing a stable supply of wood materials and alternative materials for scarce wood resources. Especially, in terms of environmental issues and resource conservation, the recycling and technological development of wood waste and agricultural waste is important, so research and development for new wood composite materials is becoming active (Hwang et al., 2020; Hwang et al., 2019; Prabuningrum et al., 2020; Jamaludin et al., 2020; Kang et al., 2019; Ju and Roh, 2019; Ju and Roh, 2020; Jung et al., 2020; Kang et al., 2019).

Among them, sawdust, by-product generated during $\log$ processing, usually produced around $10 \%$ volume ratio of the $\log$ (There could be a difference depending

\footnotetext{
${ }^{1}$ Date Received December 23, 2020, Date Accepted June 2, 2021

2 Department of Wood Science \& Technology, Jeonbuk National University, Jeonju 54896, Republic of Korea

$\dagger$ Corresponding author: Seung-Won OH (e-mail: ohsw@jbnu.ac.kr, ORCID: 0000-0002-6601-9789)
} 
on the thickness of the $\log$ and the dimensions of the $\log$ ). According to the Korea 2020 Forestry Statistical Yearbook, sawdust was produced in 2019 at 128,817 $\mathrm{m}^{3}$, KRW 19.9 billion. In accordance with the classification and recycling standards of waste wood in the Korea Ministry of Environment's Notice (Ministry of Environment Notice No. 2008 - 147), it is classified as Grade 1 and can be recycled as wood molded products. However, most of them are used as fuel for firewood, for manure treatment in livestock farms, mushroom cultivation, etc., and limitedly pulverized to be used for plastic molding, fiber wall materials and activated carbon manufacturing. In addition, rice husk, an agricultural waste, generates about 1.1 million tons of rice husk annually in Korea, weighing 20-25\% of rice production. Also, its large volume with an apparent density of $0.097 \sim 0.125 \mathrm{~g} / \mathrm{cm}^{3}$ has a problem when discard. Moreover, due to its low calorific value and high ash content, it has the disadvantage of not being easily decomposed even after buried, so it has been mainly used as agricultural compost and desiccant for pigsty (Baek et al., 1998; Kim et al., 2001). The technology development of wood materials using sawdust and rice husks has been studied in various ways.

In addition, wood materials, which were made only of existing wood materials, are gradually changing to eco-friendly materials in which functional materials are mixed. Research and development of various eco-friendly materials considering durability and functionality are being carried out (Park et al., 2011, 2012, 2013; Ahn, 2009). Among them, charcoal is a representative eco-friendly material that can be easily accessed, and although it varies depending on the manufacturing method, carbon usually accounts for about 80 to $90 \%$ of content, and is a complex carbonaceous polymer material containing oxygen, hydrogen and ash. The specific gravity of charcoal is about $0.6-0.9$, and it shows alkalinity with a $\mathrm{pH}$ of 8-9 (Seo, 2014). In addition, it has a very large specific surface area of about $100 \sim 300 \mathrm{~m}^{2}$ per $1 \mathrm{~g}$ of weight, and it is porous, so it has excellent adsorption power, so it has been used for various purposes such as air purification, deodorization, and protection from poison since ancient times. In addition, charcoal is easy to obtain, and has various functions such as deodorizing, working as a preservative, filtering, moisturizing, anion generating, and electromagnetic wave blocking performance have been highlighted, resulting in increased production and demand. So recently, a lot of research is being conducted as an important raw material for eco-friendly material research (Park et al., 2011, 2012, 2013; Ahn, 2009; Park and Park, 2011; Kim, 2017; Hwang and Oh, 2017, 2020a, 2020b).

Therefore, in this study, to examine the use of charcoal, sawdust, and rice husk, which are eco-friendly functional materials, mixed boards were manufactured by density and mixing ratio, and bending performance was measured.

\section{MATERIALS and METHODS}

\subsection{Materials}

\subsubsection{Sawdust}

Sawdust we used was made when sawing larch (Larix kaemferi C.) cut down by thinning and we purchased from a commercial sawmill. As shown in Fig. 1, using a sorter (Shinchang co., vibrator), it was selected at -18 mesh, and the moisture content was adjusted to $6 \%$ or less.

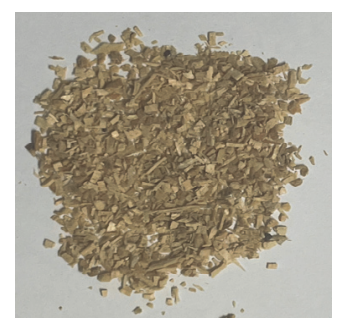

Fig. 1. Shape of sawdust. 


\subsubsection{Rice husk}

The rice husks were purchased from a rice mill in Deokjin-dong, Jeonju, and dried in the shade. As shown in Fig. 2, in order to increase the bonding strength when manufacturing the board, it was pulverized with a pulverizer (Hanshin co., J-NCM), the particle size was selected as -18 mesh, and the moisture content was adjusted to $6 \%$ or less.

\subsubsection{Charcoal}

Oak charcoal was purchased and used in -100mesh size from Geumhan Farm Co., Ltd. in Imsil.

\subsubsection{Resin}

Due to the characteristics of the thermo-presser used for manufacturing, it has a disadvantage in that it is difficult to discharge moisture, so a powdered phenolic resin (Kolon Petrochemical Co., Ltd., KNB-100PL) was used to manufacture the board, and the characteristics of the resin are shown in Table 1.

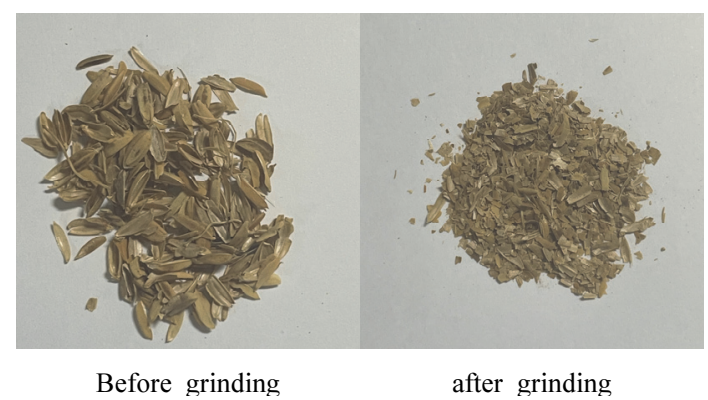

Fig. 2. Shape of rice husk before and after grinding.

Table 1. Characterisitcs of phenol-formaldehyde resin for the test

\begin{tabular}{cc}
\hline Resin types & $\begin{array}{c}\text { Powder resin } \\
\text { (novolak type) }\end{array}$ \\
\hline \hline Solid content $(\%)$ & 99 \\
Melting point $\left({ }^{\circ} \mathrm{C}\right)$ & $80 \sim 95$ \\
Gelation time $(\mathrm{sec})$. & $80 \sim 120$ \\
Plate flow $(\mathrm{mm})$ & $30 \sim 35$ \\
\hline
\end{tabular}

\subsection{Test Methods}

\subsubsection{Board Manufacturing}

As for the manufacturing conditions of the board, the resin addition ratio was fixed at $10 \%$ of the total weight, the density was fixed at $0.6 \mathrm{~g} / \mathrm{cm}^{3}$, and the addition amount of sawdust, rice husk and charcoal was varied to $50: 35: 5,50: 30: 10,50: 25: 15$, and 50:20:20 to prepare 4 types. The amount of sawdust, rice husk and charcoal was fixed at 50:20:20 and the density was set to 3 types of $0.5,0.6,0.7 \mathrm{~g} / \mathrm{cm}^{3}$. Uniformly selected sawdust, rice husk and charcoal was sufficiently mixed with the powdered phenolic resin and it was placed in a mold on the hot plate of a thermo-presser (Daeyang Machinery, DYMSP-001-026), the height of the upper part of the sample was adjusted to a certain level, and then a board of $260 \mathrm{~mm} \times 260 \mathrm{~mm} \times 11$ $\mathrm{mm}$ was manufactured by thermo-press molding. At this time, the temperature was set to $170^{\circ} \mathrm{C}$, and the pressure was $40 \mathrm{~kg} / \mathrm{cm}^{2} \rightarrow 30 \mathrm{~kg}_{\mathrm{f}} / \mathrm{cm}^{2} \rightarrow 20 \mathrm{~kg} / \mathrm{cm}$ (three-stage pressurization), 9 minutes $\rightarrow 2$ minutes $\rightarrow$ 1 minutes (three-stage pressurization time). A thickness bar was used to make the thickness of the board constant during the hot-pressing process, and a Teflon plate was used to prevent adhesion of the top and bottom of the board to the hot plate due to heat. Fig. 3 is a picture of the finished board.

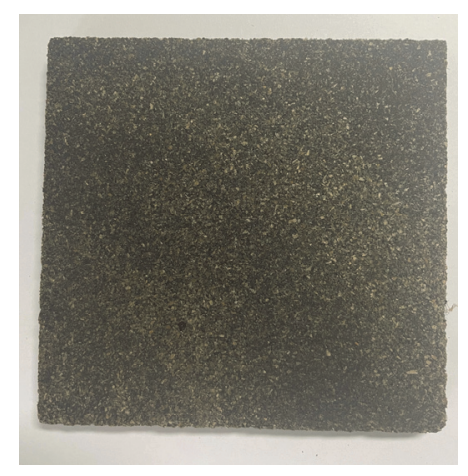

Fig. 3. Appearance of the composite board manufactured from sawdust, rice husk and oak charcoal. 


\section{3. physical property measurement}

\subsubsection{Measurement of dynamic modulus of elasticity}

An accelerometer $(\mathrm{B} \& \mathrm{~K})$ for vibration reception was attached to the center of the specimen, and one end was lightly tapped with an impact hammer (Type $8203, \mathrm{~B} \& \mathrm{~K})$ to obtain a frequency response function from the impact hammer and accelerometer. With this, the natural frequency $\left(\mathrm{f}_{0}\right)$ was measured by using a signal analyzer (FFT analyzer, Type 3065, B\&K). Each test piece was tapped 5 times, and the average natural frequency $\left(f_{0}\right)$ was used to calculate the resonance frequency (f) considering the rotational inertia and shear effect, and the dynamic modulus of elasticity (dMOE) was calculated using this resonance frequency. The standard of the test piece used for the test was measured by selecting 8 pieces for each condition using the bending strength test piece specified in Korean Industrial Standard KS F 3104-2006.

\subsubsection{Bending test}

The bending strength and static bending modulus of the manufactured board were selected for 8 each condition and carried out according to the Korean Industrial Standards KS F 3104-2006. It was measured at a load speed of $10 \mathrm{~mm} / \mathrm{min}$ using a universal strength tester (Shimadsu, AGS-10 kN, Autograph).

\section{RESULTS and DISCUSSION}

\subsection{Effect of Density on Bending Performance}

Table 2 shows the measured values of the resonant frequency, bending strength, static bending modulus and dynamic modulus of elasticity (One of the non-destructive test methods that do not change the performance of the end-use of the material) of boards manufactured by density with the addition ratio of sawdust, rice husk and charcoal as 50:20:20 with the $10 \%$ of resin addition ratio. As the density of the board made of sawdust, rice husk and charcoal increases from 0.5 $\mathrm{g} / \mathrm{cm}^{3}$ to $0.7 \mathrm{~g} / \mathrm{cm}^{3}$; the resonant frequency increases from $102.2 \mathrm{~Hz}$ to $268.3 \mathrm{~Hz}$, Bending strength increases from $0.42 \mathrm{MPa}$ to $3.24 \mathrm{MPa}$, the dynamic modulus of elasticity increases from 888.4 MPa to $94.5 \mathrm{MPa}$, the static modulus of elasticity increases from 31.4 MPa to $220.7 \mathrm{MPa}$. In determining the mechanical properties of the board, the density of the board is an important determining factor, and in general, the mechanical properties increase as the density of the board increases. As the density increases, the amount of crushed sawdust, rice husk and charcoal increases. As

Table 2. Properties of composite boards made at different density

\begin{tabular}{|c|c|c|c|c|c|c|c|c|c|}
\hline \multirow{2}{*}{ Mixing ratio ${ }^{* 1}$} & \multirow{2}{*}{$\begin{array}{c}\text { Denstiy } \\
\left(\mathrm{g} / \mathrm{cm}^{3}\right)\end{array}$} & \multicolumn{2}{|c|}{$\mathrm{RF}$} & \multicolumn{2}{|c|}{ MOR } & \multicolumn{2}{|c|}{$\mathrm{dMOE}$} & \multicolumn{2}{|c|}{ sMOE } \\
\hline & & $(\mathrm{Hz})$ & $\mathrm{p}$-value & $(\mathrm{MPa})$ & $\mathrm{p}$-value & $(\mathrm{MPa})$ & $\mathrm{p}$-value & $(\mathrm{MPa})$ & p-value \\
\hline \multirow{3}{*}{$50: 20: 20$} & 0.5 & $\begin{array}{c}102.2 \\
(12.34)\end{array}$ & \multirow{3}{*}{0.000} & $\begin{array}{c}0.42 \\
(0.03)\end{array}$ & \multirow{3}{*}{0.000} & $\begin{array}{c}94.5 \\
(22.73)\end{array}$ & & $\begin{array}{c}31.4 \\
(6.94)\end{array}$ & \multirow{3}{*}{0.000} \\
\hline & 0.6 & $\begin{array}{c}219.8 \\
(38.36)\end{array}$ & & $\begin{array}{c}2.27 \\
(1.00)\end{array}$ & & $\begin{array}{c}546.6 \\
(215.05)\end{array}$ & 0.000 & $\begin{array}{c}136.1 \\
(43.65)\end{array}$ & \\
\hline & 0.7 & $\begin{array}{c}268.3 \\
(37.12)\end{array}$ & & $\begin{array}{c}3.24 \\
(0.98)\end{array}$ & & $\begin{array}{c}888.4 \\
(266.75)\end{array}$ & & $\begin{array}{c}220.7 \\
(62.37)\end{array}$ & \\
\hline
\end{tabular}

*1: mixing ratio (sawdust : rice husk : charcoal)

RF: resonant frequency

MOR: modulus of rupture

dMOE: dynamic modulus of elasticity

SMOE: static modulus of elasticity 


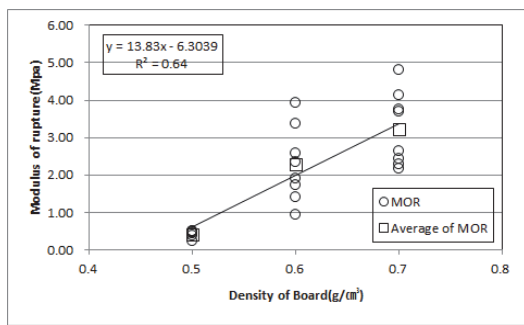

(a)

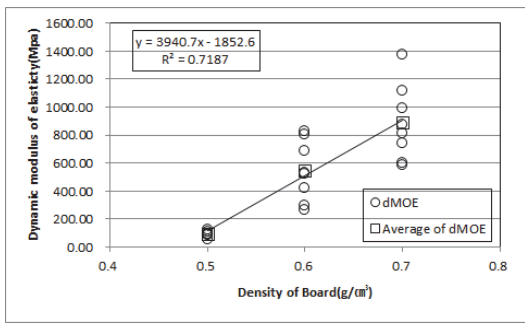

(c)

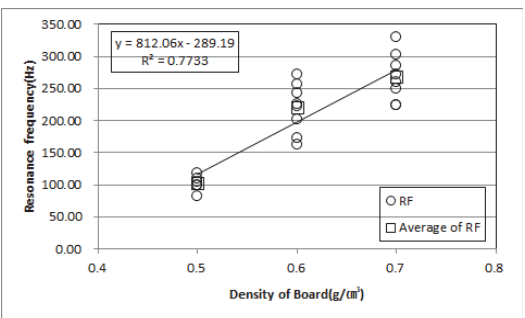

(b)

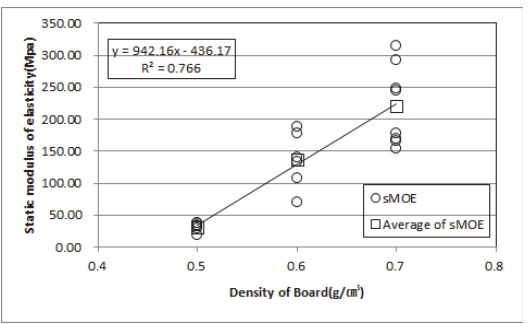

(d)

Fig. 4. Relation between density and mechanical properties of composite boards (a): relation between density and modulus of rupture (MOR) (b): relation between density and resonance frequency (RF), (C): relation between sawdust addition ratio and dynamic modulus of elasticity (dMOE), (d): relation between sawdust addition ratio and static modulus of elasticity (sMOE)).

the density increases, the amount of sawdust and rice husk in particle form increases more than the amount of charcoal powder. Therefore, when the molded mat is pressed, it is thought that the higher the density of the board, the denser the spacing and structure between the particles of the board, thereby strengthening the bonding force and thus the bending performance is increased. Also, Oh (2003) reported that the bending strength increased as the density of sawdust boards made of sawdust from the Trees cut down after thinning increased, and Piao (2004) reported that the bending strength increased rapidly as the density of mixed boards made of sawdust and rice husks increased. Also, Jin et al. (2015) reported that the bending performance increased as the density of boards made of sawdust and orange peel increased.

On the other hand, each correlation with the board density and bending strength, the resonant frequency, the dynamic modulus of elasticity and the static bend- ing modulus of elasticity was analyzed to determine the effect on the strength performance of each density of the board manufactured with the raw material ratio of sawdust, rice husk and charcoal as 50:20:20 with the resin addition rate as $10 \%$. The result is shown in Fig. 4. The coefficient of determination $\left(\mathrm{R}^{2}\right)$ between the sawdust addition ratio, bending strength, and dynamic and static bending modulus of elasticity showed a correlation of $0.6400,0.7733,0.7187$, and 0.7660 , respectively. This was found to be significant at the significance level of $1 \%$, and it was found that the density was a major factor affecting the bending performance of the mixed board.

\subsection{Effect of rice husk and charcoal addition rate on bending performance}

Table 3 shows the values of the resonant frequency, bending strength, static bending modulus of elasticity, and dynamic modulus of elasticity of a board manu- 
Table 3. Properties of composite boards made at different mixing ratio

\begin{tabular}{|c|c|c|c|c|c|c|c|c|c|}
\hline \multirow{2}{*}{$\begin{array}{c}\text { Denstiy } \\
\left(\mathrm{g} / \mathrm{cm}^{3}\right)\end{array}$} & \multirow{2}{*}{$\begin{array}{l}\text { Mixing } \\
\text { ratio*1 }^{*}\end{array}$} & \multicolumn{2}{|c|}{$\mathrm{RF}$} & \multicolumn{2}{|c|}{ MOR } & \multicolumn{2}{|c|}{ dMOE } & \multicolumn{2}{|c|}{ sMOE } \\
\hline & & $(\mathrm{Hz})$ & p-value & (MPa) & $\mathrm{p}$-value & (MPa) & $\mathrm{p}$-value & (MPa) & $\mathrm{p}$-value \\
\hline \multirow{4}{*}{0.6} & $50: 35: 5$ & $\begin{array}{l}295.39 \\
(38.88)\end{array}$ & \multirow{3}{*}{0.000} & $\begin{array}{c}4.69 \\
(1.57)\end{array}$ & \multirow{4}{*}{0.000} & $\begin{array}{l}1026.45 \\
(323.66)\end{array}$ & \multirow{4}{*}{0.000} & $\begin{array}{l}361.15 \\
(73.02)\end{array}$ & \multirow{4}{*}{0.000} \\
\hline & $50: 30: 10$ & $\begin{array}{l}248.93 \\
(53.03)\end{array}$ & & $\begin{array}{c}2.68 \\
(1.15)\end{array}$ & & $\begin{array}{c}798.05 \\
(338.26)\end{array}$ & & $\begin{array}{l}214.51 \\
(86.83)\end{array}$ & \\
\hline & $50: 25: 15$ & $\begin{array}{l}238.92 \\
(23.81)\end{array}$ & & $\begin{array}{c}2.42 \\
(0.75)\end{array}$ & & $\begin{array}{c}643.7 \\
(140.93)\end{array}$ & & $\begin{array}{c}178.28 \\
(54.79)\end{array}$ & \\
\hline & $50: 20: 20$ & $\begin{array}{l}205.02 \\
(31.45)\end{array}$ & & $\begin{array}{c}1.81 \\
(0.59)\end{array}$ & & $\begin{array}{c}456.3 \\
(159.76)\end{array}$ & & $\begin{array}{l}136.13 \\
(43.65)\end{array}$ & \\
\hline
\end{tabular}

*1: mixing ratio (sawdust : rice husk : charcoal)

RF: resonant frequency

MOR: modulus of rupture

dMOE: dynamic modulus of elasticity

sMOE: static modulus of elasticity

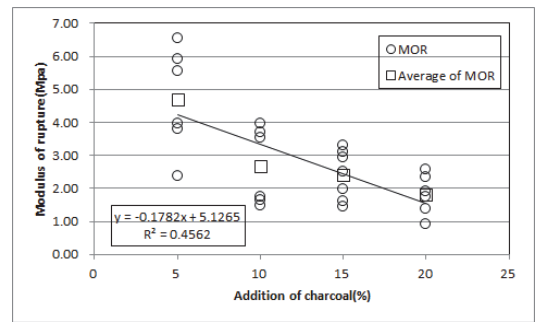

(a)

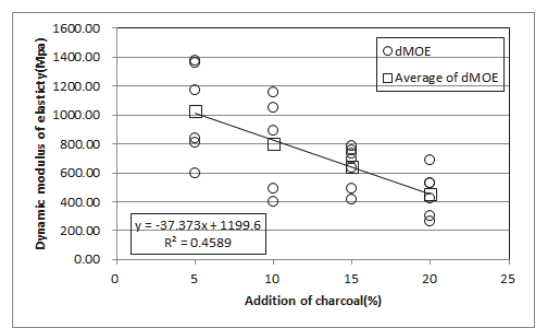

(c)

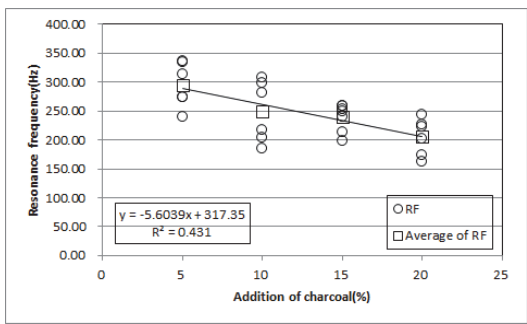

(b)

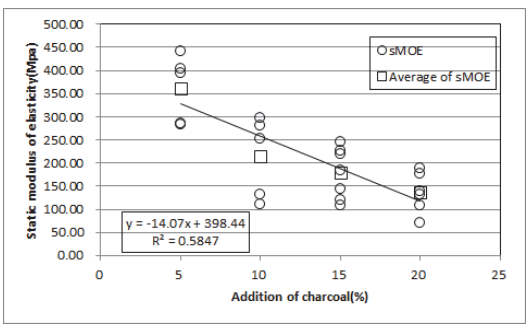

(d)

Fig. 5. Relation between addition of charcoal and mechanical properties of composite boards (a): relation between density and modulus of rupture (MOR) (b): relation between density and resonance frequency (RF), (c): relation between sawdust addition ratio and dynamic modulus elasticity (dMOE), (d): relation between sawdust addition ratio and static modulus of elasticity (sMOE)).

factured with a sawdust addition rate of $50 \%$ and Manufactured at a density of $0.6 \mathrm{~g} / \mathrm{cm}^{3}$ by varying the addition ratio of rice husk and charcoal. When the charcoal addition ratio among the rice husk and charcoal addition ratios of the mixed board is increased from 5 to $20 \%$, the resonance frequency had a range of $295.39 \sim 205.02 \mathrm{~Hz}$, the bending strength was $4.69 \sim$ $1.81 \mathrm{MPa}$, the dynamic modulus was $1026.45 \sim 456.31 \mathrm{MPa}$, and the static modulus of elasticity was in the range of 361.15 to $136.13 \mathrm{MPa}$. Overall, the resonant fre- 
quency, bending strength, dynamic modulus of elasticity and static modulus of elasticity tend to decrease as the addition ratio of rice husk decreased and the addition ratio of charcoal increased. This is considered to be the result of weakening the internal bonding force by reducing the amount of compaction during board manufacturing when the addition ratio of rice husk in the particle state is less than the amount of charcoal in the powder state. Park et al. (2007) found that the strength decreased as the amount of carbide added increased in the physical properties of particleboards made from waste wood carbide. This showed a trend similar to the result reported that the strength of the carbide itself was weaker than that of the particles and directly affected the internal bonding strength. Also, Park et al. (2013) reported that the overall bending strength tends to decrease as the mixing ratio of green tea and charcoal in composite boards made of green tea, charcoal, and wood fibers increases.

Meanwhile, In order to understand the effect of the addition ratio of a board manufactured with a density of $0.6 \mathrm{~g} / \mathrm{cm}^{3}$ by varying the addition ratio of rice husk and charcoal with the addition ratio of sawdust fixed at $50 \%$, the correlation between the bending strength, resonance frequency, dynamic modulus of elasticity and static bending modulus according to the addition ratio of rice husk and charcoal was analyzed. And the results are shown in Fig. 5. The coefficient of determination $\left(\mathrm{R}^{2}\right)$ between the addition ratio of rice husk and charcoal, bending strength, resonance frequency, and dynamic and static bending modulus were $0.4562,0.4310$, 0.4589 , and 0.5847 , respectively. It showed a rather low correlation, and it was found that the effect of the addition ratio on the bending performance was negligible. In the case of a composite material using two or more raw materials, it is judged that the correlation is somewhat irregular due to the difference in density and adhesion between the raw materials and the deviation generated in the process of mixing the raw materials (Park et al., 2011; Park et al., 2013; Jin et al., 2015).

\section{CONCLUSION}

In this study, an environmentally friendly material, charcoal, was added to rice husk, an agricultural by-product, and sawdust generated in the cutting logs process, and the board was manufactured according to the mixing ratio and density of rice husk and charcoal. And the following results were obtained by examining the physical and mechanical properties for use development.

As the density increases from $0.5 \mathrm{~g} / \mathrm{cm}^{3}$ to $0.7 \mathrm{~g} / \mathrm{cm}^{3}$, the bending strength is 0.42 to $3.24 \mathrm{MPa}$, the dynamic modulus of elasticity is 94.5 to $888.4 \mathrm{MPa}$, and the static modulus is in the range of 31.4 to $220.7 \mathrm{MPa}$, From this, it was confirmed that the bending performance increased as the density increased, so that the density had a significant effect on the bending performance.

In the boards manufactured by the addition ratio of rice husk and charcoal, the bending performance showed a tendency to decrease as the addition ratio of charcoal increased. However, as for the relationship between the addition ratio of rice husk and charcoal, bending strength, resonance frequency, and dynamic and static bending elastic modulus, the values of the coefficient of determination $\left(\mathrm{R}^{2}\right)$ were $0.4562,0.4310$, 0.4589 , and 0.5847 , respectively, indicating a rather low correlation. It was found that the effect of the addition ratio on the bending performance was small.

The bending performance of the composite board did not satisfy the quality standards of KS F 3104 particle board. To improve the strength performance so that it can be used as an indoor building material in the future, it is judged that a follow-up experiment is necessary with a detailed density condition and a material addition ratio condition. In addition, for practical use, research on thermal insulation and adsorption 
properties is required in consideration of the material properties of composite boards.

\section{REFERENCES}

Ahn, B.J., Jo, T.S., Lee, S.S., Paik, K.H., Kim, S.I. 2009. Utilization of charcoal as an environmentally friendly building materials( I ): Characterization of building materials prepared with charcoal. Journal of The Korean Wood Science and Technology 37(6): 537-545.

Baek, I.H., Bin, H.S., Kim, T.Y., Nam, K.C. 1998. The manufacture of activated carbon from agricultural by-products and their adsorption performance for the organics. Journal of Korean Society of environmental Engineers 20(10): 1485-1493.

Hwang, J.W., Oh, S.W. 2017. Physical and mechanical properties of board made from carbonized rice husk. Journal of the Korean Wood Science and Technology 45(1): $62-71$.

Hwang, J.W., Oh, S.W. 2020a. Properties of board manufactured from sawdust, ricehusk and charcoal. Journal of Korean wood science and technology 48(1): 61-75.

Hwang, J.W., Oh, S.W. 2020b. Mechanical performances of boards made from carbonized rice husk and sawdust: The effect of resin and sawdust addition ratio. Journal of the Korean Wood Science and Technology 48(5): 696-709

Hwang, J.W., Oh, S.W. 2019. Change of surface temperature and far-infrared emissivity in ceramics manufactured from a board mixed with sawdust and mandarin peel. Journal of the Korean Wood Science and Technology 47(1): 66-79.

Jamaludin, M.A., Bahari S.A., Zakaria, M.N., Saipolbahri, N.S. 2020. Influence of rice straw, bagasse, and their combination on the properties of binderless particleboard. Journal of the Korean Wood Science and Technology 48(1): 22-31.
Ju, S.G., Roh, J.K. 2019. The dyeing properties of woody fiber regenerated from waste MDF by reactive dyes. Journal of the Korean Wood Science and Technology 47(2): 163-177.

Ju, S.G., Roh, J.K. 2020. Manufacturing regenerated woody dyed fiber from waste MDF using natural dyes. Journal of the Korean Wood Science and Technology 48(2): 154-165.

Jung, S.Y., Yeom, D.H., Kong, R.K., Shin, G.G., Lee, K.S., Byeon, H.S. 2020. Sound absorption property of the leaves of two evergreen broad-leaved tree species, dendropanax morbiferus and fatsia japonica. Journal of the Korean Wood Science and Technology 48(5): 631-640.

Jin, T., Kang, C.W., Oh, S.W., Hwang, J.W. 2015. Effect of density and mixing ratio of mandarin peels on the bending performance of sawdust-mandarin peels particleboard. Journal of the Korean Wood Science and Technology 43(3): 364-373.

Kang, C.W., Lee, N.H., Jang, S.S., Kang, H.Y. 2019. Sound absorption coefficient and sound transmission loss of rice hull mat. Journal of the Korean Wood Science and Technology 47(3): 290-298.

Kang, C.W., Lee, E.S., Jang, S.S., Kang, H.Y., Kang, S.G., Oh, S.C. 2019. Sound absorption rate and sound transmission loss of wood bark particle. Journal of the Korean Wood Science and Technology 47(4): 425-441.

Kataoka, A., Ono, T. 1975. The relations of experimental factors to the vibration and the measuring values of dynamic mechanical properties of wood I. The experimental errors due to the measuring apparatus. Mokuzai Gakkaishi 21: 543-550.

Kim, I.B., Kim, Y.G. 2001. Recycling evaluation of rice-hull and sawdust using carborization. Journal of korean Society of Environmental Administration 7(3): 439-443.

Kim, G.C. 2017. A study on the strength properties of board using the carbonized rice husks to develop 
a structural insulation. Journal of the Korean Wood Science and Technology 45(5): 511-518.

Korea Forest Service. 2020. Statistical yearbook of forestry.

Ministry of Environment. 2008. Classification and recycling standards for waste wood.

Oh, S.W. 2003. Physical and mechanical properties of sawdust board made of thinning $\operatorname{logs}(\mathbb{I})$ : The effect of density and additive quantity of powder phenolic resin. Mokchae Konghak 31(3): 17-23.

Piao, J.J. 2004. Physical and mechanical properties of ceramics from a board mixed with sawdust and rice husk. Jeonbuk National University master's thesis.

Park, S.B., Lee, S.M., Park, J.Y., Kang, E.C. 2007. Properties and formaldehyde emission of particleboard fabricated with waste wood charcoal. Journal of the Korean Society of Furniture Design and Technology 18(3): 205-210.

Park, H.M., Heo, H.S., Sung, E.J., Nam, K.H., Lim, J.S. 2013. Effect of the kind and content of raw materials on mechanical performances of hybrid composite boards composed of green tea, charcoals and wood fiber. Journal of the Korean Wood Science and Technology 41(1): 64-76.

Park, H.M., Heo, H.S., Sung, E.J., Nam, K.H., Lim,
J.S., Byeon, H.S. 2012. Effect of the kind and content of raw materials on dynamic modulus of elasticity of hybrid composite boards composed of green tea, charcoals and wood fiber. Journal of Agriculture \& Life Science 46(6): 75-86.

Park, H.M., Lee, S.K., Seok, J.H., Choi, N.K., Kwon, C.B., Heo, H.S., Byeon, H.S., Yang, J.K., Kim, J.C. 2011. Effect of green tea content on dynamic modulus of elasticity of hybrid boards composed of green tea and wood fibers, and prediction of static bending strength performances by flexural vibration test. Journal of the Korean Wood Science and Technology 39(6): 538-547.

Park, S.B., Park, J.S. 2011. Combustion characteristics of bamboo charcoal boards. Journal of the Korean Wood Science and Technology 40(1): 19-25.

Prabuningrum, D.S., Massijaya, M.Y., Hadi, Y.S., Abdillah, I.B. 2020. Physical-Mechanical Properties of Laminated Board Made from Oil Palm Trunk (Elaeis guineensis Jacq.) Waste with Various Lamina Compositions and Densifications. Journal of the Korean Wood Science and Technology 48(2): 196-205.

Seo, I.S. 2014. Manufacture and performance evaluation of charcoal board and carbon fiber using wood waste. Chungnam National University $\mathrm{PhD}$ thesis. 


\title{
APPENDIX
}

\author{
(Korean Version)
}

\section{톱밥과 왕겨 및 숯을 이용하여 제조한 보드의 휨성능}

초록: 본 연구에서는 제재부산물인 톱밥과 농업부산물인 왕겨의 이용방안을 검토하고자 친환경재료인 솣을 첨가하여 밀도별, 혼합비율별로 혼합보드를 제조하고 휨성능을 조사하여 다음과 같은 결과를 얻었다. 톱밥과 왕겨 및 숯의 첨가율을 $50: 20: 20$, 수지첨가율을 $10 \%$ 로하여 밀도별로 제조한 혼합보드의 밀도가 $0.5 \mathrm{~g} / \mathrm{cm}^{3}$ 에서 $0.7 \mathrm{~g} / \mathrm{cm}^{3}$ 로 증가할수록 휨강도는 $0.42 \sim 3.24 \mathrm{~N} / \mathrm{mm}^{2}$, 동적탄성계수는 94.5 888.4 N/mm² 그리고 정적탄성계수는 31.4 220.7 N/mm²의 범위를 나타내, 밀도가 증가할수록 휨성능이 증가하여 밀도가 휨성능에 크게 영향을 끼쳤다. 밀도 $0.6 \mathrm{~g} / \mathrm{cm}^{3}$, 톱밥첨가율을 $50 \%$ 로 하고, 왕겨와 숯의 첨가율을 달리하여 제조한 보드에서 숯의 첨가율이 증가할수록 휨성능이 감소하는 경향을 나타냈다. 왕겨 및 숯의 첨가율과 휨강도, 공진주파수, 동적 및 정적 휨 탄성계수사이의 관계는 결정계수의 값 $\left(\mathrm{R}^{2}\right)$ 은 각각 $0.4562,0.4310,0.4589,0.5847$ 으로 다소 낮은 상관관계를 나타내 첨가율이 휨성능에 끼치는 영향은 적은 것을 알 수 있었다.

\section{1. 서론}

현대인의 생활이 대부분 실내에서 이루어지고 있어 실내 환경에 관한 문제와 개인의 건강문제에 따라 친환경 건축재 료인 목재와 목질재료에 대한 관심이 증대되고 있다. 이에 목재와 목질재료 소비량이 증대하는 상황을 대처하고, 목질원료의 안정적 수급과 부족한 목재자원의 대체원료 개발의 차원에서 목질폐기물 및 농산물 폐기물의 재활용 및 기술 개발이 환경문제와 자원보존의 측면에서 무엇보다 필요하며, 새로운 목질복합재료에 대한 연구개발이 활발해 지고 있다(Hwang et al., 2020; Hwang et al., 2019; Prabuningrum et al., 2020; Jamaludin et al., 2020; Kang et al., 2019; Ju and Roh, 2019; Ju and Roh, 2020; Jung et al., 2020; Kang et al., 2019).

그 중 원목 가공과정에서 발생되는 제재 부산물인 톱밥은 원목의 굵기와 제재목의 치수에 따라 다르지만 대체로 용적비 $10 \%$ 내외의 톱밥이 발생한다. 톱밥은 2020년 임업통계연보에 따르면 2019년에 $128,817 \mathrm{~m}^{3}, 199$ 억원정도 생산되 었다. 환경부고시(환경부고시 제2008 - 147호)에서 폐목재의 분류 및 재활용기준에 따라 1등급으로 분류되어 목재 성형제품등으로 재활용이 가능하다. 하지만 대부분이 장작등의 연료, 가축농가에서 분뇨처리용, 버섯재배등으로 사용되 고 한정적으로 미분화처리하여 플라스틱성형용, 섬유벽재용 및 활성탄 제조용으로 사용된다. 또한 농산물폐기물인 왕겨는 국내에서 연간 약 110 만 톤이 발생하여 쌀 생산량의 $20 \sim 25 \%$ 정도로 많은 양이 생산되고 있음에도 불구하고, 겉보기 밀도가 $0.097 \sim 0.125 \mathrm{~g} / \mathrm{cm}^{3}$ 이며 폐기 시 부피가 커서 문제가 되고 있으며, 낮은 발열량과 높은 회분함량으로 매립 후에도 쉽게 분해되지 않는 단점을 지니고 있어 주로 농업용 퇴비, 돈사의 방습제 등으로 사용되어 왔다(Baek et al., 1998; Kim et al., 2001). 톱밥과 왕겨를 활용한 목질재료의 기술개발은 다양한 방법으로 연구가 진행되어 왔다.

또한 여기에 목질재료는 기존의 목재소재로만 제조되던 것이 점차 기능성이 포함된 재료가 혼합된 친환경재료로 변화하고 있다. 특히, 내구성과 기능성을 고려한 다양한 친환경재료의 연구와 개발이 이루어지고 있다(Park et al., 2011, 2012, 2013; Ahn, 2009). 그 중 숯은 가장 쉽게 접할 수 있는 대표적인 친환경 재료로서 제조방법에 따라 다르지만 보통 탄소가 약 80 90\%를 차지하는 탄소체이며, 이외에 산소, 수소 및 회분을 함유하는 복잡한 탄소질 고분자 물질이 고 숯의 비중은 0.6 0.9 정도이며, $\mathrm{pH} 8 \sim 9$ 로 알칼리성을 나타낸다(Seo, 2014). 또한 표면적이 중량 $1 \mathrm{~g}$ 에 대하여 약 100 300 $\mathrm{m}^{2}$ 의 아주 큰 비표면적을 가지고 있으며, 다공성이므로 흡착력이 뛰어나서 예로부터 공기정화, 방취, 방독 등의 다양한 용도로 활용되어 왔다. 그리고 구하기 쉽다는 장점과 탈취성능, 방부성능, 여과, 조습성능, 음이온 발생효과, 전자파 차단성능 등의 여러 기능성이 부각되면서 그에 따른 생산과 수요가 증가하고 있어서 최근 친환경 재료연구에 중요한 원료로서 많은 연구가 진행되고 있다(Park et al., 2011, 2012, 2013; Ahn, 2009; Park and Park, 2011; Kim, 2017; Hwang and Oh, 2017, 2020a, 2020b).

따라서 본 연구에서는, 친환경 기능성 재료인 솣, 제재부산물인 톱밥과 농업부산물인 왕겨의 이용방안을 검토하고자 밀도별, 혼합비율별로 혼합보드를 제조하고 휨성능을 측정하였다. 


\section{2. 재료 및 방법}

\section{1. 재료}

2.1.1. 톱밥

톱밥은 낙엽송(Larix kaemferi C.) 간벌재 제재시 발생된 것을 시중 제재소에서 구입하여 사용하였으며, Fig. 1에서 보여진 것처럼 선별기(Shinchang co., vibrator)를 이용하여 $-18 \mathrm{mesh}$ 로 선별하고 함수율은 $6 \%$ 이하로 조절하였다.

\subsection{2. 왕겨}

왕겨는 전주시 덕진동 정미소에서 구입하여 음건한 후 Fig. 2에서 보여진 것처럼 보드 제조시 결합력을 높이기 위하여 분쇄기(Hanshin co., J-NCM)로 분쇄하여 입자크기를 - $18 \mathrm{mesh}$ 로 선별하고 함수율은 $6 \%$ 이하로 조절하여 사용하 였다.

\subsection{3. 숯}

참나무숯은 임실의 (주)금한팜에서 - $100 \mathrm{mesh}$ 사이즈를 구입하여 사용하였다.

\subsection{4. 수지}

제조에 이용된 열압기의 특성상 수분배출이 어렵다는 단점을 가지고 있어, 보드제조를 위하여 분말상 페놀수지(코오 롱유화(주), KNB-100PL)를 사용하였고 수지의 특성은 Table 1 과 같다.

\section{2. 시험방법}

\subsection{1. 보드제조}

보드의 제조 조건은 수지첨가율을 전체 무게의 $10 \%$ 로 고정하고 밀도를 $0.6 \mathrm{~g} / \mathrm{cm}^{3}$ 으로 고정하여, 톱밥과 왕겨 및 숯의 첨가량을 $50: 35: 5,50: 30: 10,50: 25: 15,50: 20: 20$ 으로 달리하여 4종류를 제조하였고, 톱밥과 왕겨 및 숯의 첨가량을 50:20:20으로 고정하고 밀도를 $0.5,0.6,0.7 \mathrm{~g} / \mathrm{cm}^{3} 3$ 종류로 설정하여 제조하였다. 균일하게 선별된 톱밥과 왕겨 및 숯에 분말상 페놀수지를 충분히 혼합하여, 열압기(대양기계, DYMSP-001-026)의 열판위에 있는 몰드 속에 넣고 시료상 부의 높이를 일정하게 조절한 후 열압성형 하여 $260 \mathrm{~mm} \times 260 \mathrm{~mm} \times 11 \mathrm{~mm}$ 의 보드를 제조하였다. 이때 열압온도는 $170{ }^{\circ} \mathrm{C}$ 로 설정하였고, 제조시에 적절한 수분배출을 위해 가압압력은 $40 \mathrm{~kg}_{f} / \mathrm{mm}^{2} \rightarrow 30 \mathrm{~kg}_{f} / \mathrm{cm}^{2} \rightarrow 20 \mathrm{~kg}_{f} / \mathrm{cm}^{2}(3$ 단 가압), 가압시간 9 분 $\rightarrow 2$ 분 $\rightarrow 1$ 분(3단 가압시간)으로 하였다. 열압과정에서 보드의 두께를 일정하게 하기 위하여 thickness bar를 사용하였으며, 열에 의한 보드의 상 - 하면과 열판의 부착을 방지하기 위하여 테프론 판을 사용하였다. Fig. 3 은 완성된 보드의 사진이다.

\section{3 물성측정}

\subsection{1. 동적탄성계수 측정}

시험편의 중앙에 진동수신을 위한 가속도계(accelerometer, $\mathrm{B} \& \mathrm{~K}$ )를 부착하고, 임팩트 해머(impact hammer, Type $8203, \mathrm{~B} \& \mathrm{~K})$ 로 한쪽 끝을 가볍게 두드려 임팩트햄머와 가속도계에서 얻어낸 주파수응답함수(frequency response function)를 신호 분석기(FFT analyzer, Type $3065, \mathrm{~B} \& \mathrm{~K})$ 롤 분석하여 고유진동수(f(f)를 측정하였다. 각 시험편은 5 회 가볍게 두드려 평균된 고유진동수 $\left(\mathrm{f}_{0}\right)$ 를 이용하여 회전관성과 전단영향을 고려한 공진주파수(resonance frequency, $\mathrm{f}$ )를 계산하고, 이 공진주파수를 이용하여 동적탄성계수(dMOE)를 구하였다. 시험에 이용된 시험편의 규격은 한국산업 규격 KS F 3104-2006에 명시된 휨강도 시험편을 이용해 조건별 8개를 선정하여 측정하였다.

\subsection{2. 휨시험}

제조된 보드의 휨강도와 정적 휨 탄성계수는 조건별 8개씩 선정하여 한국산업규격 KS F 3104-2006에 따라 실시하였 다. 만능강도시험기(Shimadsu, AGS-10 kN, Autograph)를 이용하여 하중속도 $10 \mathrm{~mm} / \mathrm{min}$ 조건으로 측정하였다. 


\section{3. 결과 및 고찰}

\section{1. 밀도가 휨성능에 미치는 영향}

톱밥과 왕겨 및 숯의 첨가율을 $50: 20: 20$, 수지첨가율을 $10 \%$ 로 하여 밀도별로 제조한 보드의 공진주파수, 휨강도, 정적 휨 탄성계수 및 재료의 최종 사용용도의 성능을 변화시키지 않는 비파괴 시험방법의 하나인 동적 탄성계수를 측정한 값을 Table 2에 나타냈다. 톱밥, 왕겨 및 숯으로 제조한 보드의 밀도가 $0.5 \mathrm{~g} / \mathrm{cm}^{3}$ 에서 $0.7 \mathrm{~g} / \mathrm{cm}^{3}$ 로 증가할수록 공진주파수는 $102.2 \mathrm{~Hz}$ 에서 $268.3 \mathrm{~Hz}$ 로, 휨강도는 $0.42 \mathrm{MPa}$ 에서 $3.24 \mathrm{MPa}$ 로, 동적탄성계수는 $94.5 \mathrm{MPa}$ 에서 888.4 $\mathrm{MPa}$, 그리고 정적탄성계수는 $31.4 \mathrm{MPa}$ 에서 $220.7 \mathrm{MPa}$ 로 증가하는 경향을 나타냈다. 보드의 역학적 성질을 결정하는데 있어서 보드의 밀도가 중요한 결정요소로서, 일반적으로 보드의 밀도가 증가할수록 역학적 성질이 증가한다. 이는 밀도가 높아질수록 압체되는 톱밥, 왕겨 및 숯의 양이 증가하게 되는데 특히 분말상의 숯의 양보다 파티클 형태의 톱밥과 왕겨의 양이 증가하면서 성형된 매트를 압체시키면 밀도가 높은 보드일수록 보드의 파티클 간의 간격 및 조직을 치밀하게 만들어 결합력을 강화시켜 휨성능이 증가했다고 사료된다. 또한 Oh (2003)는 간벌재로 제조한 톱밥보 드의 밀도가 증가할수록 휨강도가 증가한다고 보고하였고, Piao (2004)은 톱밥과 왕겨로 제조된 혼합보드의 밀도가 증가함에 따라 휨강도가 급격히 증가한다고 보고하였다. 또한 Jin et al. (2015)은 톱밥과 귤박으로 제조한 보드의 밀도가 증가할수록 휨성능이 증가한다고 보고한 내용과 일치하였다.

한편 톱밥과 왕겨 및 숯의 첨가율을 50:20:20, 수지첨가율을 $10 \%$ 로 하여 밀도별로 제조한 보드의 밀도가 강도적 성능에 미치는 영향을 파악하고자, 보드의 밀도와 휨강도, 공진주파수, 동적탄성계수 및 정적 휨 탄성계수와의 각각의 상관관계를 분석한 결과는 Fig. 4과 같다. 톱밥첨가율과 휨강도, 동적 및 정적 휨 탄성계수사이는 결정계수의 값 $\left(\mathrm{R}^{2}\right)$ 은 각각 $0.6400,0.7733,0.7187,0.7660$ 으로 상관관계를 나타냈는데, 이는 유의 수준 $1 \%$ 에서 유의성이 인정되어 밀도가 혼합보드의 휨성능에 큰 영향을 주는 주요인자인 것으로 나타났다.

\section{2. 왕겨와 숯의 첨가율이 휨성능에 미치는 영향}

톱밥첨가율을 $50 \%$ 로 하고, 왕겨와 숯의 첨가율을 달리하여 밀도 $0.6 \mathrm{~g} / \mathrm{cm}^{3}$ 으로 제조한 보드의 공진주파수, 휨강도, 정적 휨 탄성계수, 동적 탄성계수를 측정한 값을 Table 3에 나타냈다. 혼합보드의 왕겨 및 숯의 첨가율 중 숯의 첨가율이 $5 \sim 20 \%$ 로 증가할수록 공진주파수는 $295.39 \sim 205.02 \mathrm{~Hz}$, 휨강도는 4.69 1.81 MPa, 동적탄성계수는 $1026.45 \sim 456.31$ $\mathrm{MPa}$, 그리고 정적탄성계수는 $361.15 \sim 136.13 \mathrm{MPa}$ 의 범위를 나타냈다. 전체적으로 왕겨 및 숯의 첨가율 중 왕겨의 첨가율이 감소하고 숯의 첨가율이 증가할수록 공진주파수, 휨강도, 동적탄성계수 그리고 정적탄성계수가 감소하는 경향을 나타냈다. 이는 파티클 상태의 왕겨의 첨가율이 분말상태인 숯의 첨가량보다 적어지면, 보드제조시의 압체량이 적어져 내부결합력을 약화시킨 결과라고 사료된다. Park et al. (2007)은 폐목재 탄화물로 제조한 파티클보드의 물성에 서 탄화물의 첨가량이 증가할수록 강도가 감소하였는데, 이는 탄화물 자체의 강도가 파티클의 강도보다 약하기 때문에 내부결합력에 직접적인 영향을 미쳤다고 보고한 결과와 비슷한 경향을 나타냈다. 또한 Park et al. (2013)은 녹차, 솣, 목재섬유로 제조한 복합보드의 녹차와 숯의 배합비율이 증가함에 따라 전반적으로 휨강도가 감소하는 경향을 나타낸다고 보고하였다.

한편 톱밥첨가율을 $50 \%$ 로 하고, 왕겨와 숯의 첨가율을 달리하여 밀도 $0.6 \mathrm{~g} / \mathrm{cm}^{3}$ 으로 제조한 보드의 첨가율이 강도적 성능에 미치는 영향을 파악하고자 보드의 왕겨와 숯의 첨가율과 휨강도, 공진주파수, 동적탄성계수 및 정적 휨 탄성계수 와의 각각의 상관관계를 분석한 결과를 Fig. 5 에 나타냈다. 왕겨와 숯의 첨가율과 휨강도, 공진주파수, 동적 및 정적 휨 탄성계수사이의 결정계수 값 $\left(\mathrm{R}^{2}\right)$ 은 각각 $0.4562,0.4310,0.4589,0.5847$ 으로 다소 낮은 상관관계를 나타내, 첨가율이 휨성능에 끼치는 영향은 미미하다는 것을 알 수 있었다. 이는 두가지 이상의 원재료를 사용한 복합재료인 경우 원재료간 의 밀도차이와 접착력 차이, 원재료를 혼합하는 과정에 발생되는 편차로 인해 상관관계는 다소 불규칙한 것으로 판단된 다(Park et al., 2011; Park et al., 2013; Jin et al., 2015).

\section{4. 결론}

본 연구에서는 농업부산물인 왕겨와 제재과정에서 발생되는 톱밥에 환경 친화적인 소재인 숯을 첨가하여 왕겨와 숯의 혼합비율 및 밀도별로 보드를 제조한 후 용도개발을 위하여 물리·기계적 성질을 조사하여 다음과 같은 결과를 
얻었다.

밀도가 $0.5 \mathrm{~g} / \mathrm{cm}^{3}$ 에서 $0.7 \mathrm{~g} / \mathrm{cm}^{3}$ 로 증가할수록 휨강도는 $0.42 \sim 3.24 \mathrm{MPa}$, 동적탄성계수는 $94.5 \sim 888.4 \mathrm{MPa}$ 그리고 정적탄성계수는 31.4 220.7 MPa의 범위를 나타내, 밀도가 증가할수록 휨성능이 증가하여 밀도가 휨성능에 크게 영향을 끼쳤다는 것을 확인할 수 있었다.

왕겨와 숯의 첨가율별로 제조한 보드에서 숯의 첨가율이 증가할수록 휨성능이 감소하는 경향을 나타냈다. 하지만 왕겨 및 숯의 첨가율과 휨강도, 공진주파수, 동적 및 정적 휨 탄성계수사이의 관계는 결정계수의 값 $\left(\mathrm{R}^{2}\right)$ 은 각각 0.4562 , $0.4310,0.4589,0.5847$ 으로 다소 낮은 상관관계를 나타내 첨가율이 휨성능에 끼치는 영향은 적은 것을 알 수 있었다.

상기 복합보드의 휨성능은 KS F 3104 파티클보드의 품질기준에 만족시키지 못하였다. 추후 실내용 건축재료로서의 이용이 가능하도록 강도적 성능을 개선하기 위해 세밀한 밀도조건과 재료의 첨가비율 조건으로 후속실험이 필요할 것으로 판단된다. 또한 실용화를 위해서는 복합보드가 가진 재료적 특성을 고려하여 단열성, 흡착성 등에 관한 연구가 요구된다. 